\title{
The Second Christ, Saint Francis of Assisi and ecological consciousness
}

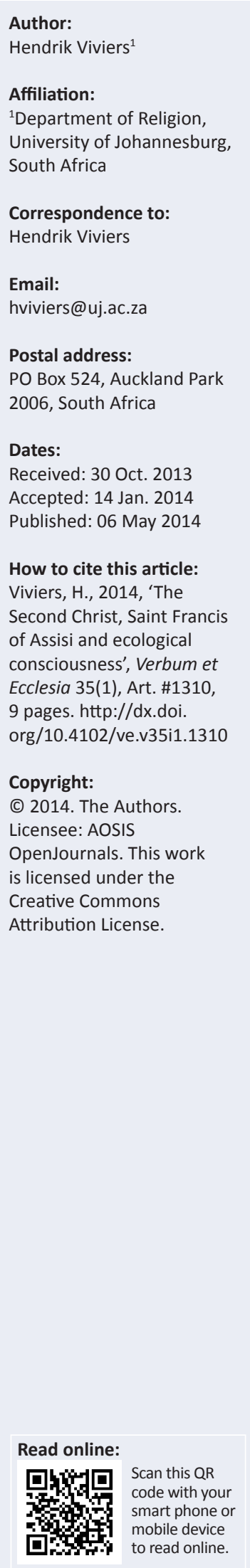

Even though the life stories of Jesus and the so-called second Christ, Francis of Assisi, incline to the fantastical, their value for a modern ecological consciousness is defendable. Behind Francis' personification of nature and his mystical experiences of nature lie an intuitive sense of interconnectedness and interdependence, of being fully part of the natural web of life (confirmed by empirical science). The same is true of the immanence of Jesus. Religious figures like Francis and Jesus can provide a sound moral attitude towards caring for the natural world, but attitudes need to be informed by scientific knowledge to act ecologically correct. A partnership between attitudes and knowledge hopefully contains good news for a sustainable 'green' planet.

Intradisciplinary and/or interdisciplinary implications: Ecological hermeneutics (part of liberation theology or hermeneutics) challenges traditional theologies' often anthropocentric bias in the intra-disciplinary arena. It respects the interconnectedness or interdependence of human and non-human life, including the non-organic, empirically substantiated by natural science. This shared realisation allows for a fruitful inter-disciplinary discourse with science to address the global ecological crisis.

\section{Introduction}

Stories are part and parcel of being human. Somewhere in our evolutionary history, we have developed narrative minds. Narrative appeals to us effortlessly whilst doing something like mathematics or physics requires hard and often tiresome effort. We are fond of creating stories and are somehow addicted to them, not always consciously aware of their shaping effects on our lives. Armstrong (1973:157) articulates this point eloquently: 'Human nature ... craves picturesque and personal anecdotes to illustrate the lives of great men and momentous turning points of history.' He adds that the value of even larger-than-life stories ' ... although mythical, have had historical and moral value ....1

Stories fluctuate between fact and fiction, and we should not be misled that only 'factually true' (irrespective of the difficulty of determining bare 'facts', especially those that lie embedded in past history) stories have meaning. Fiction, poetry and metaphor all have shaping effects on their human receivers as they carry societal values (Exum 1996:120, fn. 55). In what follows, the focus will be on the life stories of two eminent icons from Christianity. The focus will mostly be on the well-known medieval Saint Francis of Assisi and to a lesser extent on the inspiring model that he strived to emulate, Jesus. Both will be considered for their contribution to, or potential for, a modern ecological consciousness, keeping in mind that they were not 'ecologists' and lived in an era not characterised by an ecological crisis. Can the life stories of religious icons of centuries ago have any bearing on the 'greening' of our modern, scientifically informed world?

Francis, in his lifelong zeal after his conversion to follow Jesus almost literally, is for this reason sometimes aptly referred to as the Second Christ (Hooper \& Palmer 1992:77). So much so did he remind the people of his time (end of the 12th and beginning the 13th century CE) of Jesus that he similarly became idealised by his close followers. His reaching out to the poor and lesser ones of society and adopting a similar lifestyle, preaching and telling stories as he pilgrimaged around, as well as anecdotes of his miracles of changing water into wine, increasing a wine harvest, drawing water from a rock, having power over animals (see below) and so on (Sorrell 1988:47), all recalled his life model Jesus. He was especially remembered for his close relationship with nature, speaking to natural elements (water, fire, air, earth, plants, animals, etc.) as if they were family. He also easily went into ecstasy when overwhelmed by the beauty of God's creation. Can someone like this be inspiring for ecology today when, for instance, the thaumaturgical is seriously frowned upon in secular scientific circles? 
The first Jesus, the core figure of Christianity, interestingly becomes 'green' in one of the recent books of Norman Habel (2009), well-known founder of the Earth Bible Series of about a decade ago. Habel pleads for a new ecological worldview, acknowledging the interconnectedness and interdependence of all life forms and natural elements as they evolved on our planet, and he uses this ecological hermeneutical 'lens' to judge which biblical texts are 'grey' (anthropocentric) or 'green' (eco-centric or bio-centric). He finally finds special 'green meaning' in the life story of Jesus. Is there a link between the 'greenness' of Jesus and that of Francis? Does Francis pass the test if subjected to Habel's ecological worldview or consciousness? And is there a place for a 'green' Jesus, like a green Francis, in the modern ecological debate?

In what follows, Habel and his ecological hermeneutics and consequent emphasis on a green, immanent Jesus will first be introduced. This will be followed by a focus on Francis to determine the extent of his ecological consciousness and how his contextual 'greenness' can be translated in a modern, scientifically informed world.

\section{Norman Habel's (green) immanent Jesus as a guiding model for an ecological worldview}

It was former USA Vice-President Al Gore's unsettling film on the ecological crisis, An inconvenient truth, that inspired the title of Norman Habel's 2009 book, An inconvenient text, of which a brief summary follows. Habel (2009:xvi) refers back to the medieval historian Lyn White Jnr (1967), who put the blame for the ecological crisis squarely on Christianity for its views on the dualism between humanity and nature and of humanity's divine mandate to dominate the earth. The same White (1967:1207) also recommended that Francis of Assisi be honoured as the patron saint for ecologists. Although White might have been one-sided in blaming only Christianity amongst all religious traditions and not including science either, Habel concludes that White was correct in that the Bible (or some parts of it) contributed to the crude anthropocentrism of the senseless exploitation of nature. These texts he calls the 'inconvenient texts', the 'grey' texts that gave humans the green light to do with nature as they please. He instead pleads for the retrieval of the ecological good news of the 'green texts' of the Bible to supersede the ecological devastating news of the grey ones.

However, it is first necessary to undergo an ecological conversion as Pope John Paul II pleaded for at the beginning of the new millennium (Habel 2009:38). To develop a new ecological worldview would be similar to the earlier Copernican revolution. Habel (ibid) verbalises the basic tenets of such a worldview as follows:

Earth is a living planet that originated in cosmic space and evolved into a living habitat; Earth is a fragile web of interconnected and interdependent forces and domains of existence; Earth is a living community in which humans and all other organisms are kin, who live and move and have their common destiny. (p. 43)
On the notion of interconnectedness or kin, we as humans are so part and parcel of the earth, so 'made' of earth, that we ingest, incorporate and excrete the earth (Habel 2009:44, following Macy \& Seed). In his own words, Habel (2011:10) recaps succinctly: ' ... we are born of Earth, and we are living

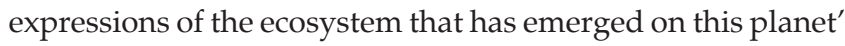
(see also Habel 2008:5; Viviers 2013). With this ecological worldview internalised, we should listen to and identify with the earth in the text as a subject, as a character in her own right.

In order to assist the ecologically conscious reader, Habel (2009:51-64) developed a three-step analysis of texts, namely suspicion, identification and retrieval. They echo the early feministic hermeneutics of suspicion and retrieval that has been taken over by eco-feminists to now read with an earth consciousness instead of a woman consciousness only. Not only patriarchy but marked anthropocentrism is exposed to retrieve the oppressed or subdued voice of earth. Habel (2000a:38-53) conflated his six older principles into these three steps:

- When reading suspiciously, a critical look is needed if Earth is stripped of her intrinsic worth and denying her (and the earthlings') purpose in the grand cosmic design.

- When putting on the identification lens, empathy with the earth is up front, bringing into focus the principles of interconnectedness and mutual custodianship, nurturing each other.

- Retrieval brings to the fore not only earth's voice of celebration but also that of resistance.

Habel has demonstrated very creatively how he goes about reading three sets of 'grey texts', namely the mandate to dominate, the mighty acts of God and the promised-land syndrome. He first reads them suspiciously to determine their inconvenient 'greyness' and then submits them to a green reading (identification, retrieval) to supersede and replace their greyness with alternative, ecologically friendly texts. For this contribution at least, the repetitive 'saving' of the Bible and of the Christian tradition with the Jesus story is very interesting. The latter serves as a meta-narrative, an ultimate answer or solution to issues raised. It also applies to each of the sets of texts finally judged in light of the Jesus story, admitting that Jesus was not in the midst of an ecological crisis as we are today (Habel 2009:75). The few examples to follow will illustrate this.

Genesis $1: 26-28$ is perhaps the mandate-to-dominate text par excellence, a grey text that is ecologically destructive, that devalues earth and gives humans a God-given right to subdue it (Habel 2009:2). Reading this text suspiciously, Habel (2000b:34-38) reiterates his former insights that the word kabash [subdue] is a harsh word, no matter how exegetes try and soften its meaning. The moment humans appear on the earthly scene, the beautiful harmony of the first part of the creation story is disrupted (Habel 2008:8). Humans, created in the image of God, act as his 'clones' (Habel 2009:4, following Sibley Towner) to have dominion over everything. 
Furthermore, this 'grey' mandate is reinforced later on (Gn 9:2) and celebrated (Ps 8). Not identifying ipso facto with the human characters but having empathy with earth as a character, Habel (ibid) indicates imaginatively what her 'voice' might sound like:

Where is the justice in such a mandate? Why should I be subdued as if I were an enemy to be placed under foot? Why should the creatures I brought to life be treated as the slaves of human beings? ${ }^{2}$ (p. 68)

Habel then presents an alternative humans-to-serve-text, Genesis 2:15: 'Then the Lord God took the man and put him in the Garden of Eden to serve and preserve it.' This is an alternative way of life, even an alternative God speaking here, not to be 'harmonised' with Genesis 1:26-28. Finally, Habel (2009:74-77) emphasises the way of Jesus, of serving rather than dominating (Mk 10:42-45). This is choosing the green rather than the grey way of life.

There are other mighty-acts-of-God texts that Habel highlights, but the Old Testament equivalent of the saving act of Jesus in the New Testament, namely the Exodus event, will suffice as an example. The plagues, the departure from Egypt and the crossing of the Reed Sea (Ex 13-14) all form part of this prominent event. Habel (2009:16-22) focuses especially on the waters of the Nile and that of the Reed Sea to demonstrate the collateral damage inflicted by God to nature in saving Israel. The Nile is 'assaulted' through the plagues (e.g. Ex 7:19) and the waters of the Reed Sea forced to swallow the Egyptians. These saving acts are suspiciously anthropocentric and ethnocentric and become destructive for earth's natural eco-systems. The celebration in Exodus 15 depicts God as a mighty warrior and not as a compassionate creator (Habel ibid:84). Empathising and retrieving the voices of these innocent receivers as the stage $\mathrm{e}^{3}$ upon which God's wrath is enacted against Israel's enemy, one can repeatedly after every plague hear the desperate call of the suffering waters of the Nile: 'We are innocent!' (Habel ibid:84). Or one can hear the call of the earth (and Reed Sea), voiced by Habel (ibid:85) as an (ironical) rhetorical question: 'I am happy that you employed my winds to disrupt the flow of the waters and destroy people ... opened my deeps so that I could swallow humans ...?' Bypassing some green texts (e.g. Ps 104; Jr 12:11; Hs $4: 1-3)$ on the way to Jesus, Habel (2009:90) finds Jesus' healing acts especially ecologically meaningful (e.g. Lk 5:17$26)^{4}$ in so far as they demonstrate Jesus' 'intimate interaction with the human body' with a spiritual dimension obviously also implied. Added to this is the act of God becoming flesh through Jesus (Jn 1:14) - 'God became a piece of Earth like Adam' (Habel 2009:94). God joins the web of creation, identifies with and permeates creation (Habel ibid:94). By

2.See also the effort of Viviers (2003) of imaginatively giving earth a 'voice' in Psalm 150.

3. In his earlier work, Habel (2000a:38-53) refers to the anthropocentric view of earth as only the 'stage', an object on which human deeds are enacted and become the main focus. He instead, pleads for earth as a co-subject in her own right.

4.Jesus' healing of the demon-possessed man in Luke 8:26-39, sending the demons into a herd of innocent, bystander pigs on a hill that led to their drowning in a lak nearby, is, however, considered by Habel (2009:90) as collateral damage and a 'grey' text. associating God so closely with nature, it begets (ultimate) intrinsic worth!

The third set of grey texts concerns the promised-land syndrome, the divine right that allowed ancient Israel to invade and possess Canaan: 'The Lord has given us this land!' (Jos 2:10). The book of Joshua has become the charter for the promised-land syndrome (Habel 2009:28), not only for Israel but for all colonising countries later on, invading the new world. As with the Exodus event, the collateral damage destroying nature continues, for example: 'With the destruction of Jericho, "oxen, sheep and donkeys" are all destroyed as an act of devotion to God' (Jos 6:21; Habel ibid:32). Ironically at the forefront, even with cosmic support (Jos 10:11-13), is the warrior God. The rights of the Canaanites who have been custodians of the land for centuries are totally ignored (Habel ibid:28). The empathising voice that Habel (ibid) gives to the land sounds as follows:

Why devote cities and landscapes to destruction rather than preservation? Why, after rescuing his people from Egypt with mighty acts of destruction, does this God feel constrained to do the same to the peoples and the land of Canaan? (p. 98)

A few green moments en route to the New Testament is the Sabbath text and the depiction of Canaan as Yahweh's sanctuary where God resides on earth (Ex 15:17; Lv 25-27). When Israel lost their land during the exile, a new promised land is depicted, a return to Eden where miraculously even the deserts will overflow with water (Is 43:19-21), the wolf and the lamb will feed together (Is 65:25) and the normal river ecosystems of earth is turned upside down in their abundance (Ezk 47). Habel (2009) lets the earth protest to these unnatural ecosystems:

Why does God suggest a future where the new Promised Land is itself alien to the very creation God has celebrated in the past? These images of a transformed land, or even heaven ${ }^{5}$ may be grand and glorious but they are hardly green - at least not as I have known green in the past. (p. 106)

When Habel again offers Jesus as the green answer to the grey inconvenience of some Bible traditions, he interestingly opts for a Jesus that is part of the here and now and not reigning in some distant celestial abode where the earth has been dissolved (e.g. 2 Pt 3:10; see also Phlp 2:4-11). He finds Romans 8:18-27 a powerful green text where, whilst creation continues, it groans together with humanity and the suffering Spirit, anticipating healing from all the wrongs done to it (Habel 2009:111). ${ }^{6}$ The cosmic Christ's suffering, reconciliation and healing effects all of creation ( $t a$ panta), not only humans (Col 2:20), and shows God '... at one with creation' (ibid:113). Habel (ibid) summarises:

The green texts identified above have tended to locate God in, with and under creation; Creation is God's sanctuary, world - or even body. The grey texts locate God outside of creation, intervening and interrupting the natural ecosystems of Earth.

5.This tunnel vision on heaven or 'heavenism' is aptly described by Habel (2009:34) as follows: '... we believers are going to heaven so to hell with Earth.'

6. Reading between the lines of its religiosity, there is the possibility of also sensing the Earth's healing itself naturally, of which the 'groaning' is the first step on its way to recovery. 
Romans 8 highlights a groaning that is common to creation, humans and the Spirit in creation: here we have an alternative to the popular notion that God, in Christ, now rules above and is no longer suffering deep in creation below. (p. 112)

Habel (2009:118) conspicuously chooses the 'story' of Jesus (idealised or divinised) or what he calls the 'Gospel principle' ${ }^{7}$ and not 'history' (historical Jesus), and he therefore accepts all its thaumaturgical elements. His book is intended for the church and therefore Habel does not (deliberately) 'demythologise' this rendering of faith ${ }^{8}$ but stays true to the master-narrative of Christianity. However, when he emphasises a specific version or nuance of the Jesus story that may have been overlooked or neglected or ignored in the past, namely a strong emphasis on the immanent Jesus instead of a transcendent Jesus, some sort of demythologisation is taking place. The immanent, earth-bound Jesus is a 'greener' Jesus than the one distancing himself from earth. Although to converse meaningfully on matters ecological with inter alia secular science does not seem to be his primary aim (at least with this book), his deliberate new emphasis of the Jesus story allows some direction in this regard. When he says that 'heavenism' and unnatural ecosystems are out (Habel 2009:34, 100-104), being part of ancient idealised versions of a new world to come, science should agree. Furthermore, the Jesus story of 'serving' the earth, taking responsibility for her as she does for us (mutual custodianship), should also provide common ground for an ethics of care into which even science might finally translate (although the ethical is not necessarily up front in the scientific discourse). If the Jesus story relates that 'earth is God's body', this metaphor confers (ultimate) intrinsic value, the highest we can confer, onto our planet and again adds an ethical dimension to our ecological awareness. Furthermore, whether understood as faith by some or just a mythical story by others, the story of Jesus' redemption and suffering along with all of creation emphasises the interconnected bond with all, the web of life, that we are all in the same ship so to speak, hopefully on our way to a better, healthier and, in terms of this contribution, a 'greener' future. Theology can provide the ethics and science the agenda for such a better world. The thaumaturgical or miraculous (but unnatural) 'lamb and wolf' lying together will, other than in pre-modern times, not be attentiongrabbing in our scientifically informed age but rather a natural Eden as it has evolved over millions of years where lamb and wolf and human have sustainable living habitats ('heavens') where they can thrive and die as nature intended it to be.

\section{The Second Christ, Saint Francis of Assisi and ecological consciousness Who was Francis?}

The life story of Francis is richly documented (see e.g. Habig 1973), and his two well-known biographers, Thomas of

\section{Habel admits that he is writing from his Lutheran background.}

8.Although Habel (2009:118) discredits the flat-Earth cosmology of the Old Testament as belonging to history, he uncritically ignores the fact that Jesus is part of precisely this cosmology.
Celano and Bonaventura, commenced with it shortly after his death. It is a rather formidable task to reconstruct or retrieve Francis from history, as with Jesus, with many of the early sources being hagiography. The latter, the writing of the lives of saints, are more than often presented as larger than life (Warner 2011:116).

Francis was born in 1181 AD in the city of Assisi, part of the Umbrian province of Italy. He came from a wealthy house - his father, Pietro Bernardone, was a well-to-do textile merchant who often visited France for his business, which most probably inspired the name Francis. As a typical young and rich libertine from the bourgeois class, Francis lived a worldly life of gambling, banquets, singing and dancing, the life of a typical, carefree troubadour (Boff 1997:206). Interestingly, his gaiety and sensuousness also characterised his later life after his conversion (Armstrong 1973:19-23; Warner 1994:228). As a typical young man, Francis considered many options as a career - merchandise (as his father), becoming a feudal nobleman, the military and so on - but none really spoke to his heart. In about 1210 or 1213, he became ill and often retracted to the caves and forests, the beautiful natural surroundings of Assisi, to contemplate and ponder on his life's direction. During these retreats, he became convinced that he should follow Christ, the Poor Man par excellence (Boff 1997:207) who emptied himself completely for others in obedience to his Father. His option for the lifestyle of the poor, pledging to marry 'Lady Poverty' (Boff 1997:207) and becoming a fool in the eyes of his former rich fellows and family, was immediately set into action. ${ }^{9}$ The Poverello (the little poor man), as his admirers fondly referred to him, began to repair small and poor churches and chapels on the margins of Assisi, promoting and embodying his new commitment to poverty. He even left the luxury of the city and his class to go and live in a leprosorium outside of the city, associating closely with the cast-out lepers. One can understand the dismay his father had for all of this. In the presence of the bishop of Assisi, he and his father had a irreparable fall-out, so much so that Francis stripped naked (for which Voltaire later on scorned him) and gave his clothes back to his father, and he determined that the habit of the church would be sufficient for his needs (Hooper \& Palmer 1992:78). Francis was not and did not become a clergyman, but as a layman, he fulfilled his mission as a kind of gospel pilgrimage (like Jesus), visiting the squares, villages and fields and not striving for the stability of the established church monasteries (Boff 1997:207). Although he followed an alternative way of 'being church' in the world, he was not opposed to the mainstream church. In 1209 or 1210, he requested approval from the Pope for his new way (rule) of poverty, chastity and obedience and was granted this in 1223. This 'new way' was also the First Order of Franciscans, later followed by his close woman friend and confidant, Clare's Second Order of Franciscans, the Poor Clares. A third order

9.Wolf (2003) criticises Francis' voluntary poverty compared to the involuntary poverty of the real poor ones of his time. He argues that Francis and his wellto-do followers had nothing to lose with this decision of endangering their lives, compared to the involuntary poor whose lives were at stake. The real poor ones compared to the involuntary poor whose lives were at stake. The real poor ones
could also not gain anything (e.g. status) with their poverty, whilst the voluntary poor could obtain a 'new' status. However, in the context of bringing his message to the rich (his audience), voluntary poverty became an effective, persuasive tool. 
followed, consisting of laymen living out their profession and wanting to become part of the Franciscan lifestyle (Boff 1997:208). In 1228, 2 years after his death in 1226 (aged 45), he was canonised a saint by Pope Gregory IX (Warner 2011:116). His most recent posthumous honouring came in 1979 when Pope John Paul II declared him the Patron Saint of Ecology.

Francis' exposure to nature during his contemplative retreats obviously enhanced his love for nature as a whole and not only for the organic forms of life. He also praised 'Brother Fire' (see Canticle below) for its warmth during the cold nights out in the open. Apart from his intuitive bond with nature, he was inspired by nature as God's book (Sorrell 1988:141), as the 'lettering' in which God communicated his beneficent power, love and care for everything (Armstrong 1973:107). It became a sign or sacrament of God's providence (Hooper \& Palmer 1992:78). Francis found God everywhere, '... whether human lepers or lowly worms' (Warner 1994:228). Even though White (1967:1206-1207) portrayed Francis as a maverick, a radical revolutionary in the church of his time with his embracing of the natural world, this was not true (Sorrell 1988:6). There were many before him who aptly demonstrated their sense of being bonded with nature, but with Francis, this became proprietary. He continued this tradition, but in becoming a nature mystic, he was new and innovative. Being overwhelmed by God's presence in creation and uniting all in kinship, his familial terms in addressing natural elements ('brother' and 'sister') came as no surprise. Many do not believe Francis to have been a sentimentalist nature romantic (Hooper \& Palmer 1992:78; Sorrell 1988:128) but that he inclined to some limited version thereof cannot be denied. Feelings cannot always be contained by the rule of sobriety and rationality. It is time to take a closer look at some demonstrations of Francis' deeply felt cosmic kinship.

\section{Some green acts of Francis exemplifying cosmic kinship}

In what follows, a few anecdotes of some of the many green acts that Francis was known for are presented. Although not presented chronologically (except for the Sermon to the Birds and the Canticle of Creatures), they are representative of Francis' encompassing love and empathy for all of creation, from God to soil and rocks and everything in between starting with 'lower' life forms, the plants and ending with his magnum opus, the Canticle. The anecdotes fluctuate between fact and fiction (often even fable-like) as can be expected from hagiographical sources, but interestingly, there are only a few that contain mythological animals (e.g. the dragon see Armstrong 1973:179). The golden thread that binds them all is Francis' deeply felt intuition and conviction of our cosmic kinship, namely '... that all living things are brothers and sisters because they have the same genetic code' (Boff 1997:211). The latter, including the evolution of earth into a living habitat (Habel's first tenet of ecological consciousness above), was obviously not known to him as a child of his premodern time, but his intuition of the bond between everything was remarkably confirmed later by empirical science. His awakening to ecological consciousness was something that was known before (Sorrell 1988), but it reached new heights in him with the realisation that everything is part of God's family, which is why he addressed them as brothers and sisters (Armstrong 1973:60).

Francis not only cared for cultivated plants but markedly wild plants as well. He insisted that his fellow friars leave a border around the community garden for wild grasses, flowers and herbs to sprout. In similar vein, he forbade the chopping down of a whole tree so that it could sprout again (Warner 1994:227-228). His valuing of the intrinsic worth of creation was taken a step further with his preaching to plants. It was shortly after his (second) 'conversion', when he preached his Sermon to the Birds (1213 AD), that he also started preaching to flowers, cornfields, vineyards, et cetera. He came to realise that this was his new calling rather than contemplative meditation and prayer as part of the eremitic lifestyle (Warner 2011:122-123). Plants should always praise God for his continued sustenance and care - and serve him. Thomas Celano, one of Francis' early biographers, emphasises just how strong his identification (see Habel's second step of ecological analysis above) with plant life was pointing out that Francis spoke to the plants as if '... they were endowed with reason' (Sorrell 1988:68). Nature, in turn, spoke to him of God with even the twigs in a hedge becoming a sacrament or sign of the cross to him (Armstrong 1973:11), easily putting him into an alternative state of rapture where he met and were united with the Creator of all (see waterfowl below). Other mystics like Douceline and Theresa of Avila continued his nature mysticism by going into ecstasy by simply looking at a flower, tree or water or listening to a bird's song (Armstrong 1973:16).

Celano tells of Francis picking up a worm on the pathway along which he was walking and putting it in the soft vegetation on the side, fearing that it would be crushed. A medieval Christological interpretation of Psalm 22:6, 'I am a worm and no man', probably inspired this action according to Celano. Alternatively, by reading Job 24:20, Francis referred to himself as 'the vilest of worms' to confess his sins. This not only illustrates his sincere empathy for and bondedness with such low life forms as worms, but it also confirms his ascription to them of intrinsic dignity, even 'rights', derived from the Divine. Francis believed that the incarnation sanctified all life and that God reveals himself even in these lowly creatures that shine with 'Divine radiance' (Armstrong 1973:143-144).

Bees impressed Francis with their diligence and foresight, and he would often speak of them for a whole day (see the Septuagint addition to $\operatorname{Pr} 6: 6-8) \cdot{ }^{10}$ It was also told that bees made a nest in one of Francis' drinking beakers which he left behind whilst retreating for prayer and contemplation in a very remote cell in a mountain. This story inclines to Franciscan romanticism or fantasy as bees would probably not nest in such a small container. His biographers' intentions

10.Francis' complete commitment to poverty and not assembling (unnecessary) earthly belongings, however, made him negative towards ants that diligently store their food in summer for the long winter ( $\operatorname{Pr} 6: 6-8 ; 30: 24-25$; Armstrong 1973:154) 
were rather to elevate his special (saintly) status instead of being correct in natural terms. A similar marvellous story is that of the cicada (cricket) which Francis kept in his cell in Portiuncula. When he called her (referring to her as 'sister') to his hand, she would come and on his command sing praises to God. Francis would often join her in singing and then send her back to her little hiding place. Armstrong (1973:155, fn. 17), however, also notes the interesting point that insects of this kind are known to duet with tapping sounds or sounds of the mouth.

Armstrong (1973:160) indicates that Francis was one of the few saints that felt empathy for fish as fish is ipso facto considered as food. It was near lake Rieti that fisherman caught a large tench which they gave to Francis. ${ }^{11}$ As he was sitting in the boat, he felt the same empathy for it as for other living things, addressed it as 'brother' and set it free. However, to 'add radiance to the saint's halo' (Armstrong 1973:161), his biographers embroidered on this anecdote the fish refused to swim away but seemed to be drawn to Francis' love. Celano relates that it swam away only after he had said a prayer whilst Bonaventura made Francis bless the fish before it went its way. It is clear that both of them idealised a revived earthly paradise like before the Fall, a paradise in which Francis was instrumental (Armstrong 1973:161).

Although Francis was not a complete maverick in his ecological consciousness but echoed many that went before him, his nature mysticism made him unique: 'Francis' nature mysticism was his most untraditional positive reaction to creation' (Sorrell 1988:79). The story most famously told to prove that Francis was a nature mystic is about the waterfowl (probably a water-hen or duck - Armstrong 1973:84) that he held in his hand and then went into ecstasy. It was again in the vicinity of lake Rieti, on his way to Greccio, that someone brought him a waterfowl that probably got stuck in fishing nets. Celano (Armstrong 1973) verbalises this incident as follows:

On receiving the bird Francis invited it to fly away, but it crouched in his hands 'as in a little nest' while the saint prayed and went into ecstasy. After a long time and 'as though coming back to himself from elsewhere', he told the waterfowl to depart and gave it his blessing. Thereupon it flew joyously away. (pp. 84-85)

Following Celano, Armstrong (1973:85) reiterates that this was probably the only instance where a saint fell into a trance whilst holding a bird. Many other legendary accounts of interactions between Francis and birds, apart from his Sermon to the Birds, were told. One example is the rescuing of turtledoves that have been caught in a trap by a young boy and making nests for them. Here they were fed by friars, reared their young and would not depart until told so by Francis. The duet with the nightingale where both Francis and the bird praised God antiphonally is another example as is the kindly falcon who kept watch over Francis, as if

11.Jesus and the miraculous catch of fish (e.g. Lk 5:1-11) probably inspired this anecdote. it had supernatural intuition, whilst he was sojourning in meditation at a place at La Verna (Armstrong 1973:52, $68,78)$. However, Francis also rebuked noisy swallows at Alviano whilst preaching, and they kept silent till the end. This legendary tale greatly impressed his audience, and they believed only someone who was a friend of the Most High could achieve such a feat. ${ }^{12}$

Moving on to mammals, it brings us to the anecdote of the Temptation by Mice. One of the severe criticisms against the ascetics of the middle ages was their negative view of nature, namely that it often harboured demons in its beauty to trap naïve humans. Despite Francis being an exception to this, he, as a child of his time, could not escape this conviction. He fell sick whilst in a cell near St Damian's and was constantly tormented by mice. Amazingly he endured this 'diabolical temptation' with cheerful patience (Armstrong 1973:184) and allowed them to keep on running over him instead of considering some kind of exorcism to drive them away. This 'grey' (see Habel above) anecdote, however, is by far overshadowed by the majority of 'green' ones, exemplifying his sincere love for nature's creatures, which also marks his contextual innovativeness (Sorrell 1988:46).

Two other 'furred beasts' (Armstrong 1973:184) that Francis lovingly reached out to were the hare and the deer. At Greccio, a leveret that was caught in a snare was brought to him. As we have become used to by now, Francis called him 'Brother Leveret' and fondly caressed him. As soon as he released the hare, it would simply jump back onto his bosom and repeated this behaviour. At long last, Francis had to ask his fellow brothers to go and release it in the woods. Here we again clearly detect the imaginative hand of hagiography. However, what we should notice behind this legendary tale's 'unnaturalness' is the highlighting of Francis' sincerity and sympathetic character, even to the extent of being feminine or maternal (Armstrong 1973:190-196). People knew he was the right person to whom to bring an injured or distressed animal. The medieval conviction that true saints have power over animals is also illustrated by Bonaventura's tale of the deer in the woods crossing Francis' path. He commanded the deer to stand still, laid his hands on him and told him to go and praise God, and only then the deer bounded away. Again we get the idea of Francis being a wonder-worker, perhaps more than an animal lover (Armstrong 1973:198) although the latter is most certainly not absent.

Still in the realm of fable-like anecdotes is the tale of the most widely known act of Francis, apart from the Sermon to the Birds and the Canticle of Creatures, namely his miraculous taming of the Wolf of Gubbio. Armstrong (1973:212) eloquently refers to this animal as 'a beast from the books, not from the woods'. This wolf, so it is told, was constantly harassing, menacing and even killing (some) of the inhabitants of Gubbio as soon as they set foot outside the

12.As Jesus (see fn. 4) had his ecological 'grey' moments, so also Francis. He cursed a pig (sow) for killing an innocent lamb, and it (the pig) died. It is told that both the dead lamb and the sow's carcass were avoided by other animals. A similar fate dead lamb and the sow's carcass were avoided by other animals. A similar fate
came upon a gluttonous robin which Francis cursed and whose dead body a cat would not eat (Armstrong 1973:113, 114). 
city walls. Francis confronted the wolf, scolded it for its past crimes for which it should be punished. However, instead of punishment, after leading him into the city, he forges a pact between the wolf and the inhabitants, namely that the wolf should refrain from tormenting them and that they should feed him (Sorrell 1988:213). One feels almost compelled to add 'and they lived happily ever after'. Even when the wolf died, he was buried in a ceremony, and a statue was erected in his memory (Hooper \& Palmer 1992:81). What is interesting about this anecdote is that the medieval mind was quite willing to ascribe morality or moral responsibility to animals but hesitant to ascribe to an animal a 'soul', a unique human quality (Armstrong 1973:203). ${ }^{13}$ The point of the wolf story is once again to highlight and enhance the saint's status of being equipped with a divinely derived power over nature. Furthermore, it symbolises the dream of complete reconciliation with nature, a return to the idyllic 'Earthly Paradise' (Armstrong 1973:202). Warner (1994:238) argues along the same line, that to even try to determine what exactly and if these events really happened is futile and missing the point. It is about the moral of the story, namely to live out this message of reconciliation. The question, however, as with Jesus above, remains - should we strive for an idealistic, biblical Earthly Paradise or rather a natural Eden?

It was about $1213 \mathrm{AD}$ that Francis experienced his Damascus experience, a 'conversion' to evangelical fervour in comparison to his previously, rather secluded, ascetic lifestyle of prayer and contemplation. After much agony in which direction his life should go, staying eremitic or choosing evangelisation through preaching, he decided on the latter after consultation with his close friends, Brother Silvester and Sister Clare. It was as if a new light had dawned on him, and he immediately set out upon his new calling. Near Bevagna, he came across some birds of different kinds in a field. They gathered around him, and there he preached his famous Sermon to the Birds. This was the event in his life for which he is remembered. Throughout the ages, this event has been represented incessantly not only in visual art, but even in our modern day, people commemorate Francis' legacy by placing a statue of him in or next to a birdbath, showing him conversing with birds. ${ }^{14}$ Francis addressed the birds as brothers or sisters ${ }^{15}$ and exhorted them to praise and thank God for his loving care of providing them with feathers as clothes, wings to fly, homes and food (as free gift). Astonishingly, so the different versions of this same event relate, the birds even reverently bowed their heads, stretched their necks, opened their beaks and spread their wings, captivated by his sermon. His hagiographers, as usual, ended the event with the saint's control of animals they would only leave after he had made the sign of the cross over them and allowed them to leave, and they even flew in

13.See again the previous footnote where both the bloodthirsty sow and gluttonous robin were held morally responsible for their deeds.

14.Modern scholars, like Dennis et al. (1996:107) and Hooper and Palmer (1992:84) amongst many others, argue for the letting go of the sentimental, even 'soppy' modern habit of people placing all kinds of figurines of Francis chatting to birds in their gardens!

15.The Fioretti, one of the early sources on Francis, lets him address the birds as 'sisters' (Armstrong 1973:60) whilst according to Thomas Celano, he called them 'brothers' (Sorrell 1988:60). the four directions of the cross in wondrous song (Armstrong 1973:59). This event became the inspiring and decisive moment for Francis to henceforth literally apply the biblical command of preaching the gospel to all creatures (Mk 16:15; Sorrell 1988:62). Francis blamed himself for not having had this broadening insight before and made it the agenda for the rest of his life. As mentioned above, Francis was the first saint to actually 'preach' to animals and so honour them. He addressed them intimately with the familial terms of brother and sister as he would his fellow friars and nuns, something that was unknown before. His identification (see Habel above) with non-human creatures as part of God's cosmic family is strongly emphasised. He acknowledged their worth by explicitly calling them 'noble' (Sorrell 1988:66). His reinterpretation of Matthew 6:25 and Luke 12:24 where birds become the vehicles to demonstrate God's providence for humans is now applied to the birds themselves. They have intrinsic worth and a special status before God (Sorrell 1988:65).

The final high point of Francis' ecological consciousness finds expression in his own writing, the Canticle of the Creatures (see a translated version in Warner 2011:114), written in Italian. This was probably the first recorded poem in Italian and inspired great minds like Dante, for instance, which makes it a remarkable achievement coming from an unschooled and unintellectual man (Sorrell 1988:125). It was written in 1225, a year before his death in 1226, which also explains the peace he made with Sister Death towards the end of the poem. He was almost blind by then and probably suffered from tuberculosis (Warner 1994:230-231). Many biblical passages, for instance Genesis 1, Psalm 104, 148, Daniel 3:57-88 and Job 38-39, to name but a few, are 'echoed' and mingled with Francis' own creative genius. The poem forms an impressive inclusio, starting and ending with praises to the most High God. In between, it is encompassing in its praise and thanks for the beauty and worth of all of nature. It not only praises the organic life forms but the non-organic elements as well. It praises Brother Sun for ${ }^{16}$ its light and splendour, reminding of God. Sister Moon and the stars capture the attention with their beauty. Brother Wind determines the weather and Sister Water gives sustenance to life. Brother Fire is praised for its heat at night, and Sister Mother Earth produces and sustains fruit, plants and herbs that we need to live from. Even forgiving humans are praised. ${ }^{17}$ And lastly, Sister Bodily Death, with whom he had made his peace and with whom he was looking forward to spend the afterlife, is also praised. The poem is not only inclusive of all of nature but, remarkably for its time, also gender inclusive (Armstrong 1973:230-231) as is clear from the now familiar Franciscan way of addressing all around him as brother and sister. It is not only the familial terms that signal the deep bond with all, but the whole poem breathes a harmonious interdependence (Sorrell 1988:133) or in the words of Warner (1994:232): 'The Canticle is remarkable for the way it points

16.The Italian word per can be understood as 'for' or 'through'. Francis could therefore praise God 'for' (causal) these natural elements' characteristics or praise God 'through or with' (instrumental) them (Sorrell 1988:129; Warner 1994:232).

17.This expression probably reflects a clash at the time between the Mayor and Bishop of Assisi. 
out a principle ecologists have only recently begun to prove scientifically: all of life is interconnected.' Francis' respect for nature is characterised by an 'I-thou' relationship instead of an 'I-it' relationship (Sorrell 1988:134, following Rosemary Reuther). It is also given its own 'voice': 'The Little Poor Man loosed the tongues of rocks and meadows to raise their voices in brotherly concord singing "Glory to God in the Highest and on earth peace"' (Armstrong 1973:242). It is remarkable how the Canticle reflects almost all of Habel's (2000a:38-53) six eco-just principles, namely intrinsic worth, interconnectedness, voice, purpose, mutual custodianship and resistance, already neatly noticed by Sorrell (1988:137) long before Habel precisely coined these principles.

So what can we learn from Francis and what not? Voltaire launched a scathing, rationalist attack on Francis and discredited him for being a mad fanatic, going about naked, speaking to beasts and catechising a wolf, someone who could hardly be taken seriously in this age of enlightenment. Such a strong verdict, however, would be missing the point of the stories, markedly those that incline more to the fictional (e.g. hagiography) as if they have nothing to offer (Armstrong 1973:169). Francis, similar to Jesus, as children of their time can obviously not offer scientific insights as to 'how' ecosystems work, but they can change attitudes towards the environment and offer meaning-seeking answers as to the 'why' of an environment at all.

In his complete submission to Jesus, Francis was deeply touched by '... the presence of the Word made flesh', of God's presence in the created order (Dennis et al. 1996:105), binding all of creation together into an interconnected web of life: 'Francis offered a spiritual description of the interdependence of an eco-system' (Warner 1994:228). He was convinced of the fraternity of all (Warner 1994:237; 2011:120), hence his addressing of the non-human elements of nature in familial or kinship terms, 'brother' and 'sister'. By doing this, he conferred intrinsic value on all other nonhuman being and evoked a lifestyle of reverence and respect. His overt personification of everything was thus a logical consequence of his faith stance. Even though Francis went to these extremes, which are admittedly not that palatable to our modern taste, personification is perhaps something that we can hardly escape, even amongst natural scientists who nowadays plead for an animal-centric personification (De Waal 2006:77). Concomitant to his personalisation of everything stood also Francis' dream of a return to an idyllic, almost non-real, Paradise marked by perfect harmony. Although deeply respecting the natural, he often inclined to an unnatural utopia in his acts toward nature (e.g. the taming of the Wolf of Gubbio), which sounds similarly naïve (as does his personification) to the modern ear. This was, however, also a consequence of his literal reading of the Bible and following Jesus (see Habel above) and the unquestioning ascription to him of thaumaturgical actions. These acts that go against nature was not a problem in the medieval context of his early followers (Sorrell 1988:17). What should not be missed behind all these miraculous anecdotes is his sincere love and empathy for all of creation.
Instead of mimicking Francis (and Jesus), what should be taken from these stories of the past is an awakening to the '... communion of life ...' and not that he (sentimentally) preached to the birds (Warner 2011:123)! Francis' overwhelming sense of the interconnectedness of all life is perhaps the outstanding characteristic of his life. This indeed made him the worthy patron saint of oecologicae cultorum or 'ecological consciousness'. It simultaneously acknowledged him as a special (moral) figure in the conversation with science, as Pope John Paul II envisaged in 1979 (Warner 2011:121). Our task today is to retrieve the green values of these icons of Christianity of the past and translate them meaningfully and creatively for the context of our contemporary culture in addressing the ecological crisis (Warner 2011:118). Francis (and Jesus) can offer alternative attitudes to a crude anthropocentrism today, namely a deep reverence, kinship, compassion and affection for the cosmic and planetary community (Boff 1997:203). Francis markedly emphasised ' ... the rights of the heart, the centrality of feeling ...' (Boff 1997:208). Emotions precede actions, they trigger what we do (De Waal 2006:18), and therefore the compassion and empathy that these icons of the past had for nature ${ }^{18}$ should become our own and inspire and energise our green acts (Sorrell 1988:128). Whilst internalising these positive feelings for the environment, it is also time to finally discard the attitude of disgust or rejection of the earthly that for so long shaped and legitimised Christianity's past exploitation of nature (White 1967). This new environmental ethics and emotional energy should be channelled and guided with ecological knowledge from the sciences (Warner 2011:126), working towards a natural Eden as we have come to know it (Habel 2009:104). Natural science, because it knows 'how' the world works, should provide the pragmatic and informed agenda for conserving the natural world. Religious figures like Francis and Jesus can inspire new ecologically conscious attitudes to provide the political (and moral) will for these endeavours and make them deeply meaningful and worthwhile. $^{19}$

\section{Conclusion}

The life stories of prominent figures of the past can have a meaningful shaping effect on modern-day ethics. Even though the stories of Jesus and Francis incline to the fantastical, their value for a modern ecological consciousness is defendable. The larger-than-life portrayals of these iconic figures of Christianity make sense in the pre-modern contexts in which they lived and should not blur their authentic sense of bondedness with all of creation. Behind Francis' personification of nature and his mystical experiences of nature lies an intuitive sense of interconnectedness and interdependence, of being fully part of the natural web of life (and confirmed by empirical science). The same is true of the immanence of Jesus. Francis and Jesus can therefore inspire a sincere respect, acknowledgement and affection for nature, an attitude of care. The right attitudes, however, also need an

18. Nelson Mandela, on own soil, functioned likewise, especially in the socio-political sphere as far as 'nation building' was concerned.

19.They can inspire both believers and unbelievers alike! 
informed agenda from science so as to act ecologically correct. To literally strive for an unnatural utopia where the 'lamb and wolf lie together' cannot, however, be taken seriously in a scientifically informed age. The point of 'harmony' behind this utopia needs to be scientifically substantiated by what science knows (and increasingly researches to know) of 'how' ecosystems work. Christianity (with other religious traditions) can and need to become partners with natural scientists in saving the planet. Attitudes and knowledge need to complement each other towards a sustainable 'green' world.

\section{Acknowledgements Competing interests}

The author declares that he has no financial or personal relationship(s) that may have inappropriately influenced him in writing this article.

\section{References}

Armstrong, E.A., 1973, Saint Francis: Nature mystic - The derivation and significance of the nature stories in the Franciscan legend, University of California Press, Berkeley.

Boff, L., 1997, Cry of the earth, cry of the poor, Orbis Books, New York.

Dennis, M., Nangle, J., Moe-Lobeda, C. \& Taylor, S., 1996, St Francis and the foolishness of God, Orbis Books, New York.

De Waal, F.B.M., 2006, Primates and philosophers: How morality evolved, Princeton University Press, Princeton.

Exum, C., 1996, Plotted, shot and painted: Cultural representations of Biblical women Sheffield Academic Press, Sheffield. (JSOT Supplement Series, 215).
Habel, N., 2000a, 'The earth Bible 1: “Guiding ecojustice principles"', in N. Habel (ed.), Readings from the perspective of earth, pp. 38-53, Sheffield Academic Press, Readings
Sheffield.

Habel, N., 2000b, 'The earth Bible 2: "Geophany: The earth story in Genesis one"', in N. Habel \& S. Wurst (eds.), The earth story in Genesis, pp. 34-48, Sheffield Academic Press, Sheffield.

Habel, N., 2008, 'SBL Symposium: "Introducing ecological hermeneutics"', in N. Habel \& P. Trudinger (eds.), Exploring ecological hermeneutics, pp. 1-8, Society of Biblical Literature, Atlanta.

Habel, N., 2009, An inconvenient text, ATF Press, Hindmarsh.

Habel, N., 2011, The birth, the curse and the greening of earth: An ecological reading of Genesis 1-11, Phoenix Press, Sheffield. (The earth Bible commentary series, 1).

Habig, M.A. (ed.), 1973, St. Francis of Assisi: Writings and Early Biographies: English omnibus of the sources for the life of St.Francis, SPCK, London.

Hooper, P. \& Palmer, M., 1992, 'World religions and ecology: "St Francis and ecology", in E. Breuilly \& M. Palmer (eds.), Chistianity and ecology, pp. 76-85, Cassell Publishers, London.

Sorrell, R.D., 1988, St Francis of Assisi and nature: Tradition and innovation in Western Christian attitudes toward the environment, Oxford University Press, Oxford.

Van den Heever, J., 2009, 'South African science and religion Forum, 13: "Creationism in the colonies: Science, religion and the legacy of apartheid in South Africa"', in C.W. du Toit (ed.), The evolutionary roots of religion: Cultivate, mutate or eliminate?, pp. 145-163, Research Institute for Theology and Religion, Unisa, Pretoria.

Viviers, H., 2003, 'Psalm 150:7ff (!): Towards an eco-theological "completion" of an unfinished symphony!', Ekklesiastikos Pharos 85(1/2), 47-61.

Viviers, H., 2013, 'Of wise ants (Prov 6:6-8; 30:24-25) and repulsive dogs (Prov 26:11): Animal and human kinship according to proverbial wisdom and natural science', Ekklesiastikos Pharos 95, 61-79.

Warner, K., 1994, 'Was St. Francis a deep ecologist?', in A.J. LaChance \& J.E. Carroll (eds.), Embracing earth: Catholic approaches to ecology, pp. 225-240, Orbis Books, New York.

Warner, K., 2011, 'Retrieving St. Francis: Tradition and innovation for our ecological vocation', in T. Winright (ed.), Green discipleship: Catholic theological ethics and the environment, pp. 114-127, Anselm Academic, Winona.

White, L. Jnr., 1967, 'The historical roots of our ecologic crisis', Science 155(3767), 1203-1207. http://dx.doi.org/10.1126/science.155.3767.1203

Wolf, K.B., 2003, Oxford studies in historical theology: The poverty of riches: St. Francis of Assisi reconsidered, Oxford University Press, Oxford. 